\title{
KEMAMPUAN BACA-TULIS AL-QUR'AN DAN PENGUATAN AGAMA SISWA MADRASAH TSANAWIYAH DI 8 KOTA BESAR DI INDONESIA
}

\author{
Erlina Farida \\ Peneliti Puslitbang Pendidikan Agama Dan Keagamaan \\ Badan Litbang \& Diklat Kementerian Agama RI \\ Jl. MH Thamrin No. 06 Jakarta Pusat \\ Email: erlinafarida999@yahoo.com
}

\begin{abstract}
Abstrak
The purpose of the research on the ability to read-write the holly Qur'an for the students of public madrasah tsanawiyah (MTs N) is to identify their development of the reading and writing skills towards the holly Qur'an, also implementing the religious empowerment program in the eight largest cities in Indonesia (Medan, Serang Jakarta, Bandung, Semarang, Yogyakarta, Surabaya, Makassar, dan Serang). The quantitative approach and statistic descriptive technique are used in identifying the reading-writing skills of the holly Qur'an. Besides, the qualitative approached is used in the implementation of religious empowerment program for the students of MTs. The result of the research reveals that the ability of reading-writing the holly Qur'an for the students of MTs $N$ in the eight largest cities is categorized in a good level. Despite the ability in writing the Qur'an appears to be lower than the reading, the average point of the writing skills is considered sufficient in such level.
\end{abstract}

Key word: Qur'an reading-writing skills, student religious empowerment, madrasah tsanawiyah.

\begin{abstract}
Abstrak
Penelitian tentang kemampuan baca-tulis Al-Qur'an siswa Madrasah Tsanawiyah Negeri (MTs N) ini dimaksudkan untuk mengetahui tingkat kemampuan membaca dan menulis Al-Qur'an dan implementasi program penguatan agama siswa di MTs N di delapan kota besar di Indonesia (Medan, Serang Jakarta, Bandung, Semarang, Yogyakarta, Surabaya, Makassar, dan Serang).. Kemampuan baca tulis Al-Qur'an menggunakan pendekatan kuantitatif serta teknik deskriptif statistik. Sedangkan implementasi program penguatan agama siswa MTs N ini dilihat melalui pendekatan kualitatif. Hasil daripenelitian ini menunjukkan bahwa kemampuan baca tulis Al-Qur'an siswa MTs $N$ di delapan kota besar di Indonesia termasuk dalam kategori baik. Namun kemampuan menulis Al-Qur'an masih lebih rendah daripada kemampuan membaca Al-Qur'an, yaitu sebagian besar siswa rata-rata kemampuan menulisnya masih dalam kategori cukup.
\end{abstract}

Kata kunci: kemampuan baca tulis Al-Qur'an, penguatan agama siswa, madrasah tsanawiyah

\section{PENDAHULUAN}

Madrasah sebagai satuan pendidikan formal, dituntut untuk meningkatkan pemahaman ilmu agama dan pengamalan ajaran Islam siswa, namun di sisi lain harus mampu menumbuhkan kemampuan peserta didik dalam memenuhi kebutuhan hidup. Menjawab problem penguatan pendidikan agama dan ciri khas keIslaman inilah Peraturan Menteri Agama nomor 2 tahun 2008 tentang Standar Kompetensi Lulusan dan Standar Isi Pendidikan Agama Islam (PAI) dan Bahasa Arab di Madrasah lahir. Adanya penambahan

Naskah diterima 29 September 2013. Revisi pertama, 22 Oktober 2013. Revisi kedua, 15 November 2013 dan revisi terahir 3 Desember 2013. 
jam pelajaran agama (Al-Qur'an-Hadits, Akidah-Akhlak, Fikih, SKI) dan Bahasa Arab dalam struktur kurikulum untuk MI dan MTs sebanyak 10 jam pelajaran, untuk MA sebanyak 8 jam pelajaran kecuali program keagamaan, merupakan upaya penguatan pendidikan agama di madrasah. Untuk mengukur ketercapaian kompetensi peserta didik sesuai dengan standar kompetensi tersebut, Kementerian Agama melakukan penilaian hasil belajar PAI dan Bahasa Arab peserta didik melalui Ujian Akhir Madrasah Berstandar Nasional (UAMBN).

UAMBN tahun Pelajaran 2010/2011 yang diatur melalui Surat Keputusan Direktur Jenderal nomor Dj.I/60/2011, tanggal 17 Januari 2011, bertujuan mengukur pencapaian hasil belajar peserta didik pada akhir suatu jenjang pendidikan, sesuai dengan Standar Kompetensi Lulusan yang ditetapkan secara nasional. UAMBN berfungsi sebagai bahan dalam pemetaan dan umpan balik untuk perbaikan program pembelajaran Pendidikan Agama Islam dan Bahasa Arab di madrasah; selain juga sebagai bahan pertanggungjawaban penyelenggaraan pendidikan madrasah kepada stakeholder pendidikan di Kementerian Agama. Adapun mata pelajaran yang diujikan pada tingkat Madrasah Ibtidaiyah dan Madrasah Tsanawiyah yaitu: Al-Qur'an-Hadis, AkidahAkhlak, Fikih, Sejarah Kebudayaan Islam, dan Bahasa Arab.

Upaya Kementerian Agama dalam pengembangan Standar Kompetensi dan Kompetensi Dasar PAI untuk madrasah ini, merupakan upaya penguatan agama dan penegasan cirikhas keIslaman pada madrasah karena dalam Peraturan Pemerintah Republik Indonesia Nomor 19 Tahun 2005 tentang Standar Nasional Pendidikan, Peraturan Menteri Pendidikan Nasional Nomor 22 dan 23 Tahun 2006 tentang Standar Isi dan Standar Kompetensi Lulusan untuk Pendidikan Dasar dan Menengah, dimana kelompok mata pelajaran agama dan akhlak mulia dalam struktur kurikulum hanya memberikan beban belajar mata pelajaran agama untuk SD/MI kelas III-VI sebanyak 3 jam pelajaran, sedangkan SMP/MTs dan SMA/MA sebanyak 2 jam pelajaran perminggu.

Pendidikan Agama Islam (PAI) di Madrasah Tsanawiyah yang terdiri atas empat mata pelajaran merupakan pilar penguatan agama bagi siswa madrasah yang kesemuanya harus diikuti dengan kemampuan membaca dan menulis Al-Qur'an yang baik. Kemampuan baca-tulis Al-Qur'an merupakan dasar dan alat penguat bagi peningkatan kemampuan agama siswa. Kemampuan baca-tulis AlQur'an mutlak harus dimiliki siswa madrasah, ditengah tuntutan kemampuan agama yang lebih pada siswa madrasah melalui standar kurikulum yang lebih tinggi. Penelitian Puslitbang Pendidikan Agama dan Keagamaan tentang "Efektivitas kebijakan pemerintah daerah tentang baca-tulis al-Qur'an dalam perspektif Peningkatan Mutu Pendidikan Agama" tahun 2010 menunjukkan adanya dukungan signifikan masyarakat maupun Pemda dalam peningkatan kemampuan baca-tulis Al-Qur'an siswa di sekolah dan madrasah. Bagaimana kemampuan membaca dan menulis Al-Qur'an siswa madrasah dan pelaksanaan penguatan agama di madrasah? Atas berbagai alasan tersebut di atas, maka penelitian tentang "Kemampuan baca-tulis Al-Qur'an dan Penguatan Agama siswa Madrasah" dilaksanakan. Fokus permasalahan studi ini adalah : Bagaimana kemampuan membaca dan menulis AlQur'an siswa di madrasah dan bagaimana implementasi program penguatan agama di madrasah berdasarkan Peraturan Menteri Agama Nomor 2 Tahun 2008?

\section{KERANGKA KONSEP}

\section{Konsep Membaca dan Menulis Al-Qur'an}

Al-Qur'an adalah kitab Allah yang diturunkan ke dunia yang harus diyakini oleh setiaporang mukmin.Berimankepadaal-Qur'an harus dibuktikan dengan mempelajarinya 
dan mengajarkannya kepada orang lain. Mempelajari al-Qur'an adalah kunci sukses hidup dunia dan akhirat. ${ }^{1}$ Dengan mempelajari al-Qur'an maka seseorang akan mempunyai banyak pengetahuan yang bermanfaat bagi diri sendiri dan orang lain. Mempelajari al-Qur'an berarti belajar membunyikan huruf-hurufnya dan menulisnya. Tentunya tingkatan ini adalah tingkatan yang paling awal dan sangat menentukan keberhasilan pembelajaran alQur'an pada tingkatan selanjutnya. Pada tingkatan lanjutan mungkin seseorang bisa mempelajari Ulumul Qur'an dan tafsir alQur'an. Namun untuk menuju kepada tingkatan ini seseorang harus menempuh tingkatan awal yaitu membaca dan menulis al-Qur'an. AlGhazali berkata," hendaklah seorang murid tidak mempelajari sebuah cabang ilmu sebelum menguasai cabang ilmu sebelumnya. ${ }^{2}$

Membaca Al-Qur'an merupakan hal pokok bagi orang Islam terkait dengan ibadah yang senantiasa dilakukan orang Muslim, seperti sholat dan lain sebagainya. Dalam perspektif pedagogik, mengajarkan baca-tulis al-Qur'an kepada anak-anak memberikan manfaat yang banyak, yakni disamping sebagai dasar untuk lancar membaca al-Qur'an (sebagai sumber ajaran agama Islam), juga ia merupakan kesempatan (momentum) yang sangat baik untuk mengajarkan nilai-nila moral, kisahkisah religius, dan perilaku terpuji kepada anak didik.

Pengertian baca tulis Al-Qur'an dapat dijelaskan secara etimologi. Baca dalam arti kata majemuknya "membaca" berarti melihat tulisan dan mengerti atau dapat melisankan yang tertulis. Sedangkan "tulis" berarti batu atau papan batu tempat menulis (dahulu banyak dipakai oleh murid-murid sekolah), kemudian kata "tulis" ditambah akhiran "an" maka menjadi kata "tulisan" (akan lebih mengarah kepada usaha memberikan pengertian dari baca tulis Al-Qur'an) maka

\footnotetext{
${ }^{1}$ Khalid Abdul Karim Allaahim. 2004. h. 5

${ }^{2}$ Said Hawwa. 1999, h. 18
}

tulisan berarti hasil menulis. ${ }^{3}$ Dari kata "baca" dan "tulis" digabungkan akan membentuk sebuah kata turunan yaitu "Baca Tulis" yang berarti suatu kegiatan yang dilaksanakan secara berurutan yaitu menulis dan membaca.

Kata "Al-Qur'an" menurut bahasa artinya bacaan sedangkan menurut istilah adalah mukjizat yang diturunkan oleh Allah kepada Nabi Muhammad Saw sebagai sumber hukum dan pedoman bagi pemeluk ajaran agama Islam, jika dibaca bernilai ibadah. ${ }^{4}$ Maka pengertian baca tulis Al-Qur'an dapat dirumuskan suatu kemampuan yang dimiliki untuk membaca dan menuliskan kitab suci Al-Qur'an.

Kemampuan membaca dan menulis yang dimaksud dalam penelitian ini adalah skill membaca Al-Qur'an sesuai kaidah-kaidah membaca antara lain: Tajwid, Makharijul huruf, dan kelancaran bacaan, sedangkan kemampuan menuliskan ayat-ayat Al-Qur'an yaitu skill dalam menuliskan rangkaian ayatayat Al-Qur'an meliputi: menuliskan huruf hijaiyah, merangkai huruf hijaiyah, dan menuliskan harakat dengan benar.

\section{Konsep Penguatan Pendidikan Agama Islam}

PP Nomor 19 tahun 2005 tentang SNP mendefinisikan bahwa Standar Isi adalah ruang lingkup materi dan tingkat kompetensi yang dituangkan dalam kriteria tentang kompetensi tamatan, kompetensi bahan kajian, kompetensi mata pelajaran, dan silabus pembelajaran yang harus dipenuhi oleh peserta didik pada jenjang dan jenis pendidikan tertentu. Sedangkan Standar Kompetensi Lulusan adalah kualifikasi kemampuan lulusan yang mencakup sikap, pengetahuan, dan keterampilan.

Merujuk pada Peraturan Menteri Pendidikan Nasional Nomor 22 Tahun 2006 Tentang standar isi, Struktur Kurikulum untuk

3 Departemen Pendidikan dan Kebudayaan RI. 1995. Kamus Besar Bahasa Indonesia . Cet. V; Jakarta: Balai Pustaka, h. 968

${ }^{4}$ Moh. Rifai. 1978. Ilmu Fighi Islam Lengkap. Semarang :PT. Karya Toha Putra, h. 17 
jenis pendidikan umum, kejuruan, dan khusus pada jenjang pendidikan dasar dan menengah dikelompokkan menjadi 5, salah satunya adalah kelompok mata pelajaran agama dan akhlak mulia; sedangkan beban belajar mata pelajaran agama untuk SD/MI kelas III-VI sebanyak 3 jam pelajaran, sedangkan SMP/MTs dan SMA/MA 2 jam pelajaran perminggu. Beban belajar menggunakan jam pembelajaran setiap minggu setiap semester dengan sistem tatap muka, penugasan terstruktur, dan kegiatan mandiri tidak terstruktur, sesuai kebutuhan dan ciri khas masing-masing.

Pendidikan Agama Islam di Madrasah Tsanawiyah terdiri atas empat mata pelajaran, yaitu: Al-Qur'an-Hadis, Akidah-Akhlak, Fikih, dan Sejarah Kebudayaan Islam. Masing-masing mata pelajaran tersebut pada dasarnya saling terkait, isi mengisi dan melengkapi. al-Qur'anhadis merupakan sumber utama ajaran Islam, dalam arti ia merupakan sumber akidahakhlak, syari'ah/fikih (ibadah, muamalah), sehingga kajiannya berada di setiap unsur tersebut. Akidah (usuluddin) atau keimanan merupakan akar atau pokok agama. Syariah/ fikih (ibadah, muamalah) dan akhlak bertitik tolak dari akidah, yakni sebagai manifestasi dan konsekuensi dari akidah (keimanan dan keyakinan hidup). Syari'ah/fikih merupakan sistem norma (aturan) yang mengatur hubungan manusia dengan Allah, sesama manusia dan dengan makhluk lainnya. Akhlak merupakan aspek sikap hidup atau kepribadian hidup manusia, dalam arti bagaimana sistem norma yang mengatur hubungan manusia dengan Allah (ibadah dalam arti khas) dan hubungan manusia dengan manusia dan lainnya (muamalah) itu menjadi sikap hidup dan kepribadian hidup manusia dalam menjalankan sistem kehidupannya (politik, ekonomi, sosial, pendidikan, kekeluargaan, kebudayaan/seni, iptek, olahraga/kesehatan, dan lain-lain) yang dilandasi oleh akidah yang kokoh. Sejarah Kebudayaan Islam merupakan perkembangan perjalanan hidup manusia muslim dari masa ke masa dalam usaha bersyariah (beribadah dan bermuamalah) dan berakhlak serta dalam mengembangkan sistem kehidupannya yang dilandasi oleh akidah.

Pengertian pendidikan secara umum yang dikaitkan dengan predikat agama Islam menimbulkan pengertian baru yang secara implisit menjelaskan karakteristikkarakteristik yang dimilikinya. ${ }^{5}$ Islam sebagai suatu sistem way of life diyakini bersifat komprehensif dan telah mengatur tata kehidupan yang di dalamnya ada bidang pendidikan. Bahkan para ilmuwan islam selalu mendefinisikan pendidikan sebagai suatu istilah yang secara Teologis merujuk kepada Islam.

Pengertian Pendidikan dengan seluruh totalitasnya dalam konteks Islam inheren dalam konotosi istilah "tarbiyah, ta'lim, dan ta'dib". Pendidikan sebagai pengejawantahan dari makna ketiga istilah tersebut mengandung makna yang luas dan dalam tentang hubungan manusia dan masyarakat serta lingkungannya yang dalam hubungannya dengan Tuhan saling berkaitan satu sama lain. ${ }^{6}$

Pendidikan Agama Islam dimaksudkan sebagai upaya mendidikkan (mengajarkan) agama Islam atau ajaran Islam dan nilainilainya, agar menjadi way of life seseorang. Dalam pengertian ini pendidikan Islam dapat berwujud: 1). Aktivitas yang dilakukan oleh seseorang atau lembaga untuk membantu seseorang atau sekelompok peserta didik dalam menanamkan dan atau menumbuhkembangkan ajaran Islam dan nilainilai; 2). Segenap fenomena atau peristiwa tertentu yang dampaknya ialah tertanamnya ajaran Islam atau nilai-nilainya pada salah satu atau beberapa pihak.

Konsep penguatan Pendidikan Agama Islam yang dimaksud dalam penelitian ini adalah segala upaya yang dilakukan madrasah dalam menambah intensitas pembelajaran agama, penambahan materi agama, maupun

${ }^{5}$ Azyumardi Azra. 2002. Pendidikan Islam: Tradisi dan Modernisasi menuju Milenium Baru. Jakarta: Logos, h. 4. ${ }^{6}$ Ibid., h. 5. 
pengembangan program-program keagamaan lainnya dalam rangka pemenuhan Permenag Nomor 2 Tahun 2008.

\section{Ruang Lingkup}

Ruang lingkup penelitian dapat dijelaskan pada table berikut ini:

Tabel 1.1

Ruang Lingkup Penelitian

\begin{tabular}{|l|l|l|}
\hline No & Variabel & Indikator \\
\hline \multirow{4}{*}{1.} & \multirow{3}{*}{ Penguatan PAI } & Pembelajaran PAI \\
\cline { 3 - 3 } & & Hasil Studi PAI \\
\cline { 3 - 3 } 2. & \multirow{3}{*}{$\begin{array}{l}\text { Membaca } \\
\text { Al-Qur'an }\end{array}$} & Program Penguatan Agama dan Keagamaan \\
\cline { 3 - 3 } & & Tajwid (hukum bacaan) \\
\cline { 3 - 3 } & & Bacaan (kelancaran bacaan) \\
\hline \multirow{3}{*}{3} & \multirow{2}{*}{$\begin{array}{l}\text { Menulis Al- } \\
\text { Qur'an }\end{array}$} & Makharijul Huruf (kefasihan bacaan) \\
\cline { 3 - 3 } & & Rangkaian Huruf \\
\cline { 3 - 3 } & & Harakat \\
\hline
\end{tabular}

\section{METODE PENELITIAN}

\section{Pendekatan Penelitian}

Penelitian ini menggunakan pendekatan kuantitatif dengan metode survei yaitu "penelitian yang mengambil sampel dari satu populasi dan menggunakan kuesioner sebagai alat pengumpulan data yang pokok.". 7 Pendekatan yang digunakan pada penelitian ini adalah pendekatankuantitatifdenganteknikdeskriptif statistik yang bertujuan untuk pengukuran yang cermat terhadap kemampuan membaca dan menulis Al-Qur'an siswa madrasah dengan menggunakan uji kompetensi dan teknik inferensial (uji t-test dan uji Anova) yang bertujuan untuk interpretasi data demografi sedangkan implementasi penguatan agama di madrasah dilakukan pendalaman secara kualitatif.

\footnotetext{
${ }^{7}$ Masri Singarimbun. 1995. Metode Penelitian Survai. Jakarta: LP3ES, h. 3
}

\section{Lokasi Penelitian}

Lokasi penelitian adalah MTsN yang berada di kota-kota besar di Indonesia, seluruh MTsN di kota tersebut dijadikan sasaran dalam penelitian ini yang secara lengkap dapat dilihat pada tabel 1.2 berikut ini.

Tabel 1.2

Lokasi Penelitian

\begin{tabular}{|l|l|l|c|c|}
\hline No & Propinsi & Kota & Jumlah MTsN & $\begin{array}{l}\text { Jumlah Siswa } \\
\text { kelas VIII }\end{array}$ \\
\hline 1 & $\begin{array}{l}\text { Sumatera } \\
\text { Utara }\end{array}$ & Kota Medan & 3 & 795 \\
\hline 2 & DKI & $\begin{array}{l}\text { Kota Jakarta } \\
\text { Barat }\end{array}$ & 6 & 971 \\
\hline 3 & Jawa Barat & Kota Bandung & 2 & 520 \\
\hline 4 & Jawa Tengah & Kota Semarang & 2 & 548 \\
\hline 5 & DIY & $\begin{array}{l}\text { Kota } \\
\text { Yogyakarta }\end{array}$ & 1 & 178 \\
\hline 6 & Jawa Timur & Kota Surabaya & 4 & 919 \\
\hline 7 & $\begin{array}{l}\text { Sulawesi } \\
\text { Selatan }\end{array}$ & Kota Makasar & 2 & 737 \\
\hline 8 & Banten & $\begin{array}{l}\text { Kabupaten } \\
\text { Serang }\end{array}$ & 2 & 432 \\
\hline Jumlah & & 22 & 5100 \\
\hline
\end{tabular}

\section{POPULASI DAN SAMPEL}

\section{Populasi}

Populasi target dalam penelitian ini adalah siswa di 22 MTsN di 8 kota besar yang berada di 8 propinsi di Indonesia. Populasi terjangkau dalam penelitian ini adalah seluruh siswa MTsN kelas VIII di wilayah survei, yaitu sejumlah 5100 siswa. Pemilihan kelas VIII dilakukan atas dasar, siswa telah mendapatkan pembelajaran PAI oleh madrasah secara memadai kurang lebih 2 tahun sehingga dapat diuji kemampuan agama dan baca tulis Al-Qur'an berdasarkan kurikulum madrasah. Khusus MTsN di DKI yang seluruh wilayahnya merupakan ibukota (kriteria kota) dilakukan pemilihan wilayah melalui undian dan dihasilkan wilayah Jakarta Barat (seluruh MTsN) sebagai sasaran penelitian mewakili DKI. 


\section{Sampel}

Teknik pengambilan sampel mengacu kepada pendapat Suharsimi Arikunto, yaitu apabila subyeknya kurang dari 100, lebih baik diambil semua sehingga penelitiannya merupakan penelitian populasi. Selanjutnya jika jumlah subyeknya lebih besar dapat diambil $10-15 \%$ atau $20-25 \%$, atau lebih. ${ }^{8}$

Dalam penelitian ini, diambil 10\% saja dari populasi yang ada yaitu seluruh siswa kelas VIII di seluruh MTsN pada wilayah penelitian, sedangkan dalam penentuan sampel dilakukan secara acak (random sampling), sehingga semua individu dalam populasi baik secara sendiri-sendiri maupun bersama diberi kesempatan yang sama untuk terpilih sebagai responden.

Maka setelah dilakukan penghitungan 10\% dari 5100 dan dibulatkan hasilnya menjadi 500. Oleh karena itu jumlah sampel tiap madrasah dibagi jumlah Rombongan Belajar (Rombel) yang ada, yaitu, 500 : $137=3,64$ dibulatkan menjadi 4. Maka sampel masingmasing madrasah adalah 4 siswa setiap rombel, sehingga jumlah sampel tiap madrasah dapat dilihat pada tabel 1.3 berikut ini.

Tabel 1.3

Jumlah Sampel Tiap Madrasah

\begin{tabular}{|l|l|c|c|c|}
\hline NO & MTsN & $\begin{array}{c}\text { Jumlah Siswa } \\
\text { Kelas VIII }\end{array}$ & Rombel & Sampel \\
\hline \multicolumn{4}{|l|}{ KOTA MEDAN PROPINSI SUMATERA UTARA } \\
\hline 1 & MTsN 1 Medan & 326 & 9 & 36 \\
\hline 2 & MTsN 2 Medan & 299 & 9 & 36 \\
\hline 3 & MTsN 3 Medan & 170 & 5 & 20 \\
\hline JAKARTA BARAT PROPINSI DKI & 171 & 4 & 16 \\
\hline 4 & $\begin{array}{l}\text { MTsN 27 Jakarta } \\
\text { Barat }\end{array}$ & 184 & 5 & 20 \\
\hline 5 & $\begin{array}{l}\text { MTsN 11 Jakarta } \\
\text { Barat }\end{array}$ & 97 & 3 & 12 \\
\hline 6 & $\begin{array}{l}\text { MTsN 10 Jakarta } \\
\text { Barat }\end{array}$ & 263 & 7 & 28 \\
\hline 7 & MTsN 8 Jakarta Barat & \multicolumn{5}{l}{} \\
\hline
\end{tabular}

${ }^{8}$ Suharsimi Arikunto. 2006. Prosedur Penelitian Suatu Pendekatan Praktek. Jakarta: Rineka Cipta, Cet.13. h, 134.

\begin{tabular}{|c|c|c|c|c|}
\hline 8 & $\begin{array}{l}\text { MTsN } 12 \text { Jakarta } \\
\text { Barat }\end{array}$ & 137 & 4 & 16 \\
\hline 9 & $\begin{array}{l}\text { MTsN } 35 \text { Jakarta } \\
\text { Barat }\end{array}$ & 119 & 3 & 12 \\
\hline \multicolumn{5}{|c|}{ KOTA BANDUNG PROPINSI JAWA BARAT } \\
\hline 10 & MTsN 1 & 266 & 7 & 28 \\
\hline 11 & MTsN 2 & 254 & 7 & 28 \\
\hline \multicolumn{5}{|c|}{ KOTA SEMARANG PROPINSI JAWA TENGAH } \\
\hline 12 & MTsN 1 Semarang & 297 & 8 & 32 \\
\hline 13 & MTsN 2 Semarang & 251 & 6 & 24 \\
\hline \multicolumn{5}{|c|}{ KOTA YOGYAKARTA PROPINSI DIY } \\
\hline 14 & MTsN 2 Yogya & 178 & 6 & 24 \\
\hline \multicolumn{5}{|c|}{ KOTA SURABAYA PROPINSI JAWA TIMUR } \\
\hline 15 & MTsN 1 Surabaya & 285 & 7 & 28 \\
\hline 16 & MTsN 2 Surabaya & 275 & 7 & 28 \\
\hline 17 & MTsN 3 Surabaya & 190 & 5 & 20 \\
\hline 18 & MTsN 1 Filial & 169 & 4 & 16 \\
\hline \multicolumn{5}{|c|}{ KOTA MAKASSAR PROPINSI SULAWESI SELATAN } \\
\hline 19 & $\begin{array}{l}\text { MTsN Model } \\
\text { Makassar }\end{array}$ & 360 & 9 & 36 \\
\hline 20 & MTsN Biringkanaya & 377 & 10 & 40 \\
\hline \multicolumn{5}{|c|}{ KABUPATEN SERANG PROPINSI BANTEN } \\
\hline 21 & MTsN Curug & 200 & 3 & 12 \\
\hline 22 & MTsN Serang & 232 & 6 & 24 \\
\hline \multicolumn{2}{|c|}{ Total } & 5100 & 134 & 536 \\
\hline
\end{tabular}

\section{Instrumen dan Teknik Pengumpulan Data}

Untuk memperoleh data yang bersifat kuantitatif instrumen berupa tes, meliputi tes membaca dan menulis Al-Qur'an untuk siswa. Sedangkan untuk kepentingan memperdalam implementasi penguatan agama dilakukan melalui wawancara pada Guru PAI, Wakil Kepala Madrasah bidang kurikulum, dan Kepala Madrasah serta ditulusuri pada dokumen programprogram penguatan agama dan keagamaan di madrasah, dokumen berupa nilai PAI dan bahasa arab siswa yang merupakan nilai murni/asli. 


\section{Teknik Analisis Data}

Untuk menganalis kategori kemampuan Membaca dan Menulis Al-Qur'an (BTQ) dan kemampuan Pendidikan Agama Islam (PAI) siswa digunakan penilaian yang mengacu pada kriteria pada tabel 1.4 berikut ini'.

Tabel 1.4

Kriteria Penelitian Kemampuan Siswa

\begin{tabular}{|cc|}
\hline ANGKA & KATEGORI \\
\hline $80-100$ & Sangat baik \\
\hline $66-79$ & Baik \\
\hline $56-65$ & Cukup \\
\hline $40-55$ & Kurang \\
\hline $30-39$ & Sangat kurang \\
\hline
\end{tabular}

Untuk menganalisis kemampuan membaca dan menulis Al-Qur'an siswa, maka penelitian ini mengukur berapa kemampuan siswa dalam membaca dan menulis Al-Qur'an. Dengan demikian yang akan ditaksir adalah rata-rata kemampuan membaca dan menulis Al-Qur'an siswa. Secara deskriptif, ukuran yang harus dihitung adalah rata-rata dari total nilai membaca dan menulis Al-Qur'an siswa

Jika kemampuan membaca dan menulis Al-Qur'an dilihat dari beberapa aspek, maka dihitung rata-rata tiap aspek dan rata-rata keseluruhan dengan menggunakan rumus:

$$
\pi=\frac{\sum X_{i}}{n}
$$

Data yang dikumpulkan dalam penelitian ini dianalisa dengan menggunakan teknik deskriptif statistik yaitu mendeskripsikan variabel penelitian yang diperoleh melalui hasil tes. Deskripsi disajikan dalam bentuk tabel dan grafik. Analisis ini akan digunakan untuk menganalisa data kuantitatif. Sedangkan data kualitatif berupa transkrip wawancara

\footnotetext{
${ }^{9}$ Daryanto. 2010. Evaluasi Pendidikan. Jakarta: Rineka Cipta, Cet.6, h. 211.
}

dan dokumen lainnya akan dianalisis melalui proses reduksi data (kategorisasi), verifikasi, dan kesimpulan. ${ }^{10}$

\section{HASIL DAN PEMBAHASAN}

Data hasil penelitian yang diperoleh adalah data berupa skor membaca dan menulis Al-Qur'an (BTQ) dan Pendidikan Agama Islam (PAI) yang diambil dari siswa-siswa kelas VIII Madrasah Tsanawiyah Negeri (MTsN). Sebagaimana dalam desain awal jumlah MTsN yang direncanakan untuk dijadikan sasaran penelitian adalah sebanyak 22 MTsN yang tersebar di 8 kota besar dari 8 propinsi di Indonesia. Dengan berbagai kendala teknis, dari sejumlah tersebut hanya diperoleh data dari 21 MTsN. Kota Makassar hanya diperoleh data dari satu MTsN dari dua MTsN yang direncanakan.

Jumlah sampel telah dihitung dan disesuaikan dengan jumlah rombel kelas VIII di masing-masing madrasah sasaran penelitian (satu rombel diwakili oleh 4 siswa). Jumlah sampel secara keseluruhan sebanyak 495 siswa dari 500 siswa (hasil pembulatan) yang direncanakan. Akan tetapi jumlah ini secara statistik telah cukup memenuhi karena pengambilan subjek (responden) untuk tiap rombel dilakukan secara acak.

\section{Demografi Responden}

Berdasarkan hasil uji t-test kemampuan membaca, menulis, dan nilai PAI siswa berdasarkan asal sekolah (SD/MI) dapat diketahui bahwa:

a. Tidak terdapat perbedaan kemampuan membaca Al-Qur'an siswa berdasarkan asal sekolah, atau dengan kata lain kemampuan membaca Al-Qur'an siswa yang berasal dari Sekolah Dasar (SD) sama dengan siswa

${ }^{10}$ Miles, Mathew B., dan Huberman, Michael A. Analisis Data Kualitatif: Buku Sumber tentang Metode-metode Baru. Terjemahan Tjetjep R. Rohidi, Jakarta: UI Press, h. 116 
yang berasal dari Madrasah Ibtidaiyah (MI).

b. Tidak terdapat perbedaan kemampuan menulis Al-Qur'an siswa berdasarkan asal sekolah, atau dengan kata lain kemampuan menulis Al-Qur'an siswa yang berasal dari SD sama dengan siswa yang berasal dari MI.

c. Tidak terdapat perbedaan kemampuan membaca dan menulis Al-Qur'an siswa berdasarkan asal sekolah, atau dengan kata lain kemampuan membaca dan menulis Al-Qur'an siswa yang berasal dari SD sama dengan siswa yang berasal dari MI.

d. Terdapat perbedaan kemampuan PAI siswa berdasarkan asal sekolah, atau dengan kata lain siswa yang berasal dari SD memiliki kemampuan PAI yang berbeda dengan siswa yang berasal dari MI.

Berdasarkan hasil uji ANOVA kemampuan membaca siswa berdasarkan pendidikan orang tua, pekerjaan orang tua, tempat tinggal siswa, tempat belajar Al-Qur'an siswa, dan frekuensi membaca Al-Qur'an siswa dapat dijelaskan secara ringkas sebagai berikut:

\begin{tabular}{|l|l|l|l|l|}
\hline Category & $\begin{array}{l}\text { Test of } \\
\text { Homogenity } \\
\text { of Variances } \\
\text { (Sig.) }\end{array}$ & $\begin{array}{l}\text { Kete- } \\
\text { rangan }\end{array}$ & ANOVA & Keterangan \\
\hline $\begin{array}{l}\text { Tempat } \\
\text { Belajar }\end{array}$ & 0,022 & $\begin{array}{l}\text { Varians } \\
\text { tidak } \\
\text { identik }\end{array}$ & 0,001 & $\begin{array}{l}\text { Terdapat perbedaan } \\
\text { kemampuan } \\
\text { membaca Al-Qur'an } \\
\text { berdasarkan tempat } \\
\text { belajar siswa }\end{array}$ \\
\hline Frek. \\
Membaca
\end{tabular}

Berdasarkan hasil uji ANOVA kemampuan menulis siswa berdasarkan pendidikan orang tua, pekerjaan orang tua, tempat tinggal siswa, tempat belajar Al-Qur'an siswa, dan frekuensi membaca Al-Qur'an siswa dapat dijelaskan secara ringkas sebagai berikut:

\begin{tabular}{|l|l|l|l|l|}
\hline Category & $\begin{array}{l}\text { Test of } \\
\text { Homogenity } \\
\text { of Variances } \\
\text { (Sig.) }\end{array}$ & $\begin{array}{l}\text { Kete- } \\
\text { rangan }\end{array}$ & ANOVA & Keterangan \\
\hline $\begin{array}{l}\text { Tempat } \\
\text { Belajar }\end{array}$ & 0,182 & $\begin{array}{l}\text { Varians } \\
\text { identik }\end{array}$ & 0,002 & $\begin{array}{l}\text { Terdapat perbedaan } \\
\text { kemampuan } \\
\text { menulis Al-Qur'an } \\
\text { berdasarkan tempat } \\
\text { belajar }\end{array}$ \\
\hline $\begin{array}{l}\text { Frek. } \\
\text { Membaca }\end{array}$ & 0,042 & $\begin{array}{l}\text { Varians } \\
\text { tidak } \\
\text { identik }\end{array}$ & 0,002 & $\begin{array}{l}\text { Terdapat perbedaan } \\
\text { kemampuan } \\
\text { menulis Al-Qur'an } \\
\text { berdasarkan frekuensi } \\
\text { membaca Al-Qur'an } \\
\text { siswa }\end{array}$ \\
\hline
\end{tabular}

Berdasarkan hasil uji ANOVA kemampuan membaca dan menulis (BTQ) siswa berdasarkan pendidikan orang tua, pekerjaan orang tua, tempat tinggal siswa, tempat belajar Al-Qur'an siswa, dan frekuensi membaca Al-Qur'an siswa hasilnya adalah sebagai berikut:

\begin{tabular}{|l|l|l|l|l|}
\hline Category & $\begin{array}{l}\text { Test of } \\
\text { Homogenity } \\
\text { of Variances } \\
\text { (Sig.) }\end{array}$ & $\begin{array}{l}\text { Kete- } \\
\text { rangan }\end{array}$ & ANOVA & Keterangan \\
\hline $\begin{array}{l}\text { Tempat } \\
\text { Belajar }\end{array}$ & 0,022 & $\begin{array}{l}\text { Varians } \\
\text { tidak } \\
\text { identik }\end{array}$ & 0,001 & $\begin{array}{l}\text { Terdapat perbedaan } \\
\text { kemampuan } \\
\text { membaca dan } \\
\text { menulis Al-Qur'an } \\
\text { berdasarkan tempat } \\
\text { belajar siswa }\end{array}$ \\
\hline $\begin{array}{l}\text { Frek. } \\
\text { Membaca }\end{array}$ & 0,205 & $\begin{array}{l}\text { Varians } \\
\text { identik }\end{array}$ & 0,005 & $\begin{array}{l}\text { Terdapat perbedaan } \\
\text { kemampuan } \\
\text { membaca dan } \\
\text { menulis Al-Qur'an } \\
\text { berdasarkan } \\
\text { frekuensi membaca } \\
\text { Al-Qur'an siswa }\end{array}$ \\
\hline
\end{tabular}

\section{Kemampuan Membaca Al-Qur'an}

Dari sejumlah data yang dapat dianalisis, diperoleh deskripsi statistik untuk skor variabel membaca Al-Qur'an dari masingmasing madrasah dan dari keseluruhan madrasah yang dapat dilihat pada tabel 2.2 dan grafik 2.1 berikut ini. 
Tabel 2.2

Hasil Pengolahan Data Variabel Membaca Al-Qur'an

\begin{tabular}{|lc|}
\hline Madrasah & Membaca \\
\hline MTsN 2 Makasar & 74.59 \\
\hline MTsN 1 Semarang & 71.87 \\
\hline MTsN 2 Semarang & 71.92 \\
\hline MTsN 8 JKT & 72.50 \\
\hline MTsN 11 JKT & 68.20 \\
\hline MTsN 10 JKT & 73.50 \\
\hline MTsN 12 JKT & 66.67 \\
\hline MTsN 27 JKT & 73.58 \\
\hline MTsN 35 JKT & 75.42 \\
\hline MTsN 1 BDG & 77.26 \\
\hline MTsN 2 BDG & 67.87 \\
\hline MTsN 1 SBY & 77.86 \\
\hline MTsN 2 SBY & 72.86 \\
\hline MTsN 3 SBY & 71.36 \\
\hline MTsN Rungkut SBY & 68.85 \\
\hline MTSN Kota Serang & 76.10 \\
\hline MTsN 1 Curug Serang & 67.92 \\
\hline MTsN 2 Jogja & 78.96 \\
\hline MTsN 1 Medan & 73.18 \\
\hline MTsN 2 Medan & 74.80 \\
\hline MTsN 3 Medan & 69.55 \\
\hline Rata-rata & 72.61 \\
\hline
\end{tabular}

Berdasarkan tabel 2.2 diatas dapat diketahui bahwa rata-rata kemampuan membaca Al-Qur'an siswa adalah sebesar 72.61. Hal ini berarti kemampuan membaca Al-Qur'an siswa termasuk dalam kategori baik karena berada pada rentang nilai $66-79$. Sedangkan Jika dilihat pada grafik 2.1 dapat diketahui bahwa terdapat beberapa madrasah yang masih memiliki nilai kemampuan membaca dibawah rata-rata, seperti tergambar pada grafik dibawah ini:

Grafik 2.1

Hasil Pengolahan Data Membaca Al-Quran

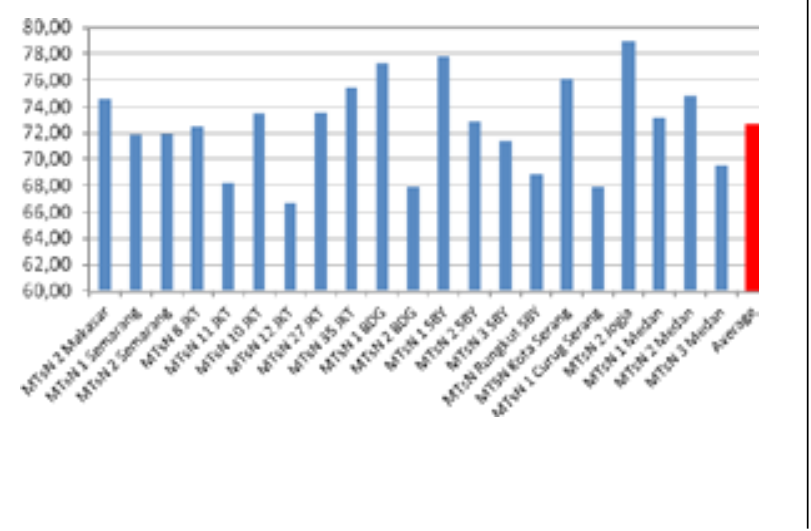

Selanjutnya data distribusi frekuensi kemampuan membaca Al-Qur'an pada 21 madrasah dalam penelitian ini ditunjukkan pada tabel 2.3 berikut ini.

Tabel 2.3

Distribusi Frekuensi Kemampuan Membaca Al-Qur'an

\begin{tabular}{|l|l|l|}
\hline Kriteria & Freq. & $\%$ Freq. \\
\hline Sangat baik & 0 & $0 \%$ \\
\hline Baik & 21 & $100 \%$ \\
\hline Cukup & 0 & $0 \%$ \\
\hline Kurang & 0 & $0 \%$ \\
\hline Sangat kurang & 0 & $0 \%$ \\
\hline Total & 21 & $100 \%$ \\
\hline
\end{tabular}

Berdasarkan tabel 2.3 diatas dapat diketahui bahwa, berdasarkan jumlah sampel penelitian sebanyak 21 madrasah, kemampuan membaca Al-Qur'an siswa pada seluruh madrasah termasuk dalam kategori baik yaitu sebanyak 21 madrasah (100\%).

Dalam penelitian ini, kemampuan membaca Al-Qur'an siswa diukur dengan menggunakan 3 indikator kemampuan yaitu bacaan, tajwid, dan makhraj. Distribusi frekuensi data kemampuan bacaan, tajwid, dan makhraj AlQur'an secara lengkap dapat dilihat pada tabel 2.4 berikut ini.

Tabel 2.4

Distribusi Frekuensi Data Indikator Kemampuan Membaca Al-Qur'an Siswa

\begin{tabular}{|l|l|l|l|l|l|l|l|}
\hline \multirow{2}{*}{ Keterangan } & \multicolumn{3}{l|}{ Bacaan } & \multicolumn{2}{l|}{ Tajwid } & \multicolumn{2}{l|}{ Makhraj } \\
\cline { 2 - 7 } & Freq & $(\%)$ & \multicolumn{2}{l|}{ Freq } & $(\%)$ & Freq & $(\%)$ \\
\hline Average & \multicolumn{2}{|l|}{75.39} & \multicolumn{2}{l|}{71.58} & 72.08 \\
\hline Sangat baik & 236 & $48 \%$ & 154 & $31 \%$ & 157 & $32 \%$ \\
\hline Baik & 164 & $33 \%$ & 180 & $36 \%$ & 189 & $38 \%$ \\
\hline Cukup & 71 & $14 \%$ & 119 & $24 \%$ & 123 & $25 \%$ \\
\hline Kurang & 23 & $5 \%$ & 42 & $8 \%$ & 26 & $5 \%$ \\
\hline Sangat kurang & 0 & $0 \%$ & 0 & $0 \%$ & 0 & $0 \%$ \\
\hline Total & 494 & $100 \%$ & 495 & $100 \%$ & 495 & $100 \%$ \\
\hline
\end{tabular}

Berdasarkan tabel 2.4 di atas, dapat dijelaskan bahwa: 
a. Pada indikator bacaan, rata-rata kemampuan bacaan Al-Qur'an siswa adalah sebesar 75.39, hal ini berarti kemampuan bacaan Al-Qur'an siswa termasuk dalam kategori baik karena berada pada rentang nilai 66 - 79. Selanjutnya berdasarkan data distribusi frekuensi dapat dijelaskan bahwa, dari 494 siswa, sebanyak 236 orang (48\%) adalah siswa yang memiliki kemampuan bacaan yang sangat baik, 164 orang (33\%) termasuk dalam kategori baik, 71 orang (14\%) termasuk dalam kategori cukup, dan sisanya sebanyak 23 orang (5\%) termasuk dalam kategori kurang, dan tidak ada siswa yang termasuk dalam kategori sangat kurang.

b. Pada indikator tajwid, rata-rata kemampuan tajwid Al-Qur'an siswa adalah sebesar 71.58, hal ini berarti kemampuan tajwid Al-Qur'an siswa termasuk dalam kategori baik karena berada pada rentang nilai 66 - 79. Selanjutnya berdasarkan data distribusi frekuensi dapat dijelaskan bahwa, dari 495 siswa, sebanyak 154 orang (31\%) adalah siswa yang memiliki kemampuan tajwid yang sangat baik, 180 orang (36\%) termasuk dalam kategori baik, 119 orang (24\%) termasuk dalam kategori cukup, dan sisanya sebanyak 42 orang (8\%) termasuk dalam kategori kurang, dan tidak ada siswa yang termasuk dalam kategori sangat kurang.

c. Pada indikator makhraj, rata-rata kemampuan makhraj Al-Qur'an siswa adalah sebesar 72.08, hal ini berarti kemampuan makhraj Al-Qur'an siswa termasuk dalam kategori baik karena berada pada rentang nilai 66 - 79 . Selanjutnya berdasarkan data distribusi frekuensi dapat dijelaskan bahwa, dari 495 siswa, sebanyak 157 orang (32\%) adalah siswa yang memiliki kemampuan makhraj yang sangat baik, 189 (38\%) termasuk dalam kategori baik, 123 (25\%) termasuk dalam kategori cukup, dan sisanya sebanyak 26 orang (5\%) termasuk dalam kategori kurang, dan tidak ada siswa yang termasuk dalam kategori sangat kurang.

\section{Kemampuan Menulis Al-Qur'an}

Dari sejumlah data yang dapat dianalisis, diperoleh deskripsi statistik untuk skor variabel menulis Al-Qur'an dari masing-masing madrasah dan dari keseluruhan madrasah yang dapat dilihat pada tabel 2.5 dan grafik 2.2 berikut ini.

Tabel 2.5

Hasil Pengolahan Data Variabel Menulis Al-Qur'an

\begin{tabular}{|ll|}
\hline Madrasah & Menulis \\
\hline MTsN 2 Makasar & 64.38 \\
\hline MTsN 1 Semarang & 72.05 \\
\hline MTsN 2 Semarang & 60.38 \\
\hline MTsN 8 JKT & 51.51 \\
\hline MTsN 11 JKT & 61.40 \\
\hline MTsN 10 JKT & 79.31 \\
\hline MTsN 12 JKT & 47.71 \\
\hline MTsN 27 JKT & 66.85 \\
\hline MTsN 35 JKT & 70.14 \\
\hline MTsN 1 BDG & 76.33 \\
\hline MTsN 2 BDG & 58.63 \\
\hline MTsN 1 SBY & 62.56 \\
\hline MTsN 2 SBY & 55.95 \\
\hline MTsN 3 SBY & 73.94 \\
\hline MTsN Rungkut SBY & 63.75 \\
\hline MTSN Kota Serang & 78.31 \\
\hline MTsN 1 Curug Serang & 60.22 \\
\hline MTsN 2 Jogja & 56.94 \\
\hline MTsN 1 Medan & 71.36 \\
\hline MTsN 2 Medan & 73.25 \\
\hline MTsN 3 Medan & 64.73 \\
\hline Rata-rata & 65.22 \\
\hline
\end{tabular}

Berdasarkan tabel 2.5 diatas dapat diketahui bahwa rata-rata kemampuan menulis Al-Qur'an siswa adalah sebesar 65.22. Hal ini berarti kemampuan menulis Al-Qur'an siswa termasuk dalam kategori cukup karena berada pada rentang nilai 56 - 65. Jika dilihat pada grafik 2.2 dapat diketahui bahwa terdapat beberapa madrasah yang masih memiliki nilai kemampuan menulis dibawah rata-rata. 
Grafik 2.2

Hasil Pengolahan Data Menulis Al-Quran

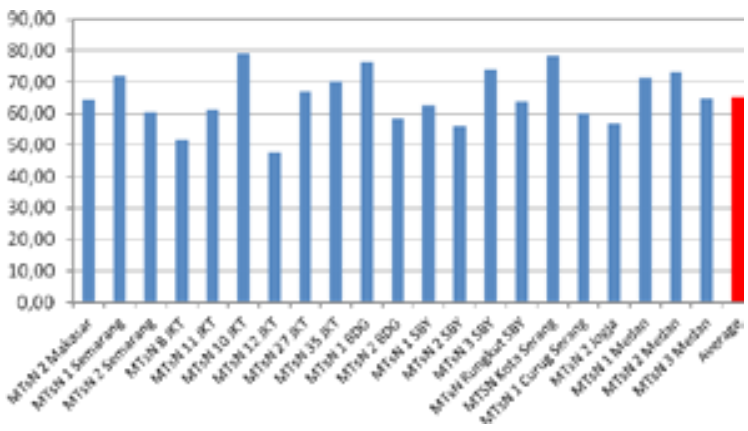

Selanjutnya data distribusi frekuensi kemampuan menulis Al-Qur'an pada 21 madrasah yang termasuk dalam sampel penelitian ini, ditunjukkan pada tabel 2.6 sebagai berikut:

Tabel 2.6

Distribusi Frekuensi Kemampuan Menulis Al-Qur'an

\begin{tabular}{|l|l|l|}
\hline Kriteria & Freq. & $\%$ Freq. \\
\hline Sangat baik & 0 & $0 \%$ \\
\hline Baik & 9 & $43 \%$ \\
\hline Cukup & 12 & $57 \%$ \\
\hline Kurang & 0 & $0 \%$ \\
\hline Sangat kurang & 0 & $0 \%$ \\
\hline Total & 21 & $100 \%$ \\
\hline
\end{tabular}

Berdasarkan tabel 2.6 diatas dapat diketahui bahwa, berdasarkan jumlah sampel penelitian sebanyak 21 madrasah, kemampuan menulis Al-Qur'an sebanyak 12 madrasah (57\%) termasuk dalam kategori cukup dan sisanya sebanyak 9 madrasah (43\%) termasuk dalam kategori baik, dan tidak ada madrasah yang termasuk dalam kategori sangat baik, kurang, dan sangat kurang.

Pada penelitian ini, kemampuan menulis Al-Qur'an siswa diukur dengan menggunakan 3 indikator kemampuan yaitu huruf, merangkai, dan harakat. Data distribusi frekuensi kemampuan huruf, merangkai, dan harakat AlQur'an secara lengkap dapat dilihat pada tabel 2.7 berikut ini.
Tabel 2.7

Distribusi Frekuensi Indikator Kemampuan Menulis Al-Qur'an Siswa

\begin{tabular}{|c|c|c|c|c|c|c|}
\hline \multirow{2}{*}{ Keterangan } & \multicolumn{2}{|c|}{ Huruf } & \multicolumn{2}{|c|}{ Merangkai } & \multicolumn{2}{|c|}{ Harakat } \\
\hline & Freq & $(\%)$ & Freq & $(\%)$ & Freq & (\%) \\
\hline Average & \multicolumn{2}{|c|}{65.88} & \multicolumn{2}{|c|}{62.91} & \multicolumn{2}{|c|}{66.87} \\
\hline Sangat baik & 112 & $23 \%$ & 89 & $18 \%$ & 121 & $24 \%$ \\
\hline Baik & 123 & $25 \%$ & 106 & $21 \%$ & 144 & $29 \%$ \\
\hline Cukup & 136 & $28 \%$ & 130 & $26 \%$ & 111 & $22 \%$ \\
\hline Kurang & 112 & $23 \%$ & 153 & $31 \%$ & 107 & $22 \%$ \\
\hline Sangat kurang & 12 & $2 \%$ & 17 & $3 \%$ & 12 & $2 \%$ \\
\hline Total & 495 & $100 \%$ & 495 & $100 \%$ & 495 & $100 \%$ \\
\hline
\end{tabular}

Berdasarkan tabel 2.7 di atas, dapat dijelaskan bahwa:

- Pada indikator huruf, rata-rata kemampuan huruf Al-Qur'an siswa adalah sebesar 65.88, hal ini berarti kemampuan huruf Al-Qur'an siswa termasuk dalam kategori cukup karena berada pada rentang nilai $56-65$. Selanjutnya berdasarkan data distribusi frekuensi dapat dijelaskan bahwa, dari 495 siswa, sebanyak 112 orang (23\%) adalah siswa yang memiliki kemampuan huruf AlQur'an yang sangat baik, 123 orang (25\%) termasuk dalam kategori baik, 136 orang (28\%) termasuk dalam kategori cukup, 112 orang (23\%) termasuk dalam kategori kurang, dan sisanya sebanyak 12 orang (2\%) termasuk dalam kategori sangat kurang.

- Pada indikator merangkai, rata-rata kemampuan merangkai Al-Qur'an siswa adalah sebesar 62.91, hal ini berarti kemampuan merangkai Al-Qur'an siswa termasuk dalam kategori cukup karena berada pada rentang nilai 56 - 65. Selanjutnya berdasarkan data distribusi frekuensi dapat dijelaskan bahwa, dari 495 siswa, sebanyak 89 orang (18\%) adalah siswa yang memiliki kemampuan merangkai AlQur'an yang sangat baik, 106 orang (21\%) termasuk dalam kategori baik, 130 orang (26\%) termasuk dalam kategori cukup, 153 orang (31\%) termasuk dalam kategori kurang, dan sisanya sebanyak 17 orang (3\%) termasuk dalam kateogir sangat kurang. 
- Pada indikator harakat, rata-rata kemampuan harakat Al-Qur'an siswa adalah sebesar 66.87, hal ini berarti kemampuan harakat Al-Qur'an siswa termasuk dalam kategori baik karena berada pada rentang nilai 65 - 79. Selanjutnya berdasarkan data distribusi frekuensi dapat dijelaskan bahwa, dari 495 siswa, sebanyak 121 orang (24\%) adalah siswa yang memiliki kemampuan harakat yang sangat baik, 144 orang (29\%) termasuk dalam kategori baik, 111 orang (22\%) termasuk dalam kategori cukup, 107 orang (22\%) termasuk dalam kategori kurang, dan sisanya sebanyak 12 orang (2\%) termasuk dalam kategori sangat kurang.

\section{Kemampuan Membaca dan Menulis Al-Qur'an}

Dari sejumlah data yang dapat dianalisis, diperoleh deskripsi statistik untuk skor variabel membaca dan menulis Al-Qur'an dari masing-masing madrasah dan dari keseluruhan madrasah yang dapat dilihat pada tabel 2.8 dan grafik 2.3 berikut ini.

Tabel 2.8

Hasil Pengolahan Data Variabel Membaca dan Menulis Al-Qur'an

\begin{tabular}{|ll|}
\hline Madrasah & BTQ \\
\hline MTsN 2 Makasar & 69.49 \\
\hline MTsN 1 Semarang & 71.96 \\
\hline MTsN 2 Semarang & 66.15 \\
\hline MTsN 8 JKT & 62.01 \\
\hline MTsN 11 JKT & 64.80 \\
\hline MTsN 10 JKT & 76.40 \\
\hline MTsN 12 JKT & 57.19 \\
\hline MTsN 27 JKT & 70.22 \\
\hline MTsN 35 JKT & 72.78 \\
\hline MTsN 1 BDG & 76.80 \\
\hline MTsN 2 BDG & 63.25 \\
\hline MTsN 1 SBY & 70.21 \\
\hline MTsN 2 SBY & 64.40 \\
\hline MTsN 3 SBY & 72.65 \\
\hline MTsN Rungkut SBY & 66.30 \\
\hline MTSN Kota Serang & 77.20 \\
\hline MTsN 1 Curug Serang & 64.07 \\
\hline
\end{tabular}

\begin{tabular}{|ll|}
\hline MTsN 2 Jogja & 67.88 \\
\hline MTsN 1 Medan & 72.31 \\
\hline MTsN 2 Medan & 74.48 \\
\hline MTsN 3 Medan & 67.24 \\
\hline Average & 68.94 \\
\hline
\end{tabular}

Berdasarkan tabel 2.8 diatas dapat diketahui bahwa rata-rata kemampuan membaca dan menulis Al-Qur'an siswa adalah sebesar 68.94. Hal ini berarti kemampuan membaca dan menulis Al-Qur'an siswa termasuk dalam kategori baik karena berada pada rentang nilai 66 - 79. Jika dilihat pada grafik 2.3 dapat diketahui bahwa terdapat beberapa madrasah yang masih memiliki nilai kemampuan membaca dan menulis dibawah rata-rata.

Grafik 2.3

Hasil Pengolahan Data Membaca dan Menulis Al-Quran

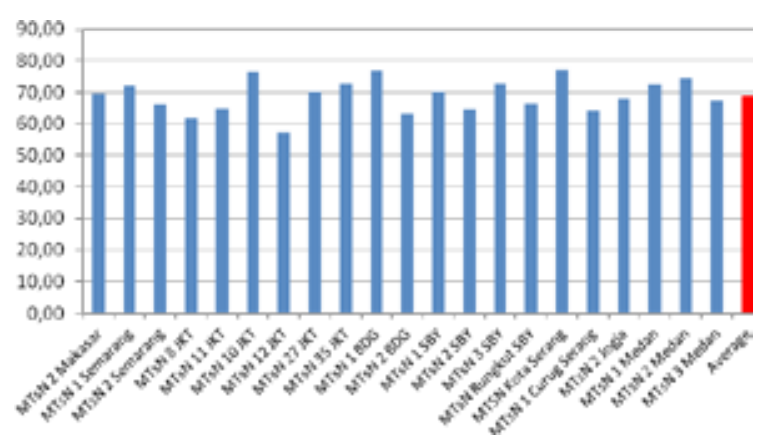

Selanjutnya data distribusi frekuensi kemampuan membaca dan menulis Al-Qur'an pada 21 madrasah yang termasuk dalam sampel penelitian, ditunjukkan pada tabel 2.9 berikut ini.

Tabel 2.9

Distribusi Frekuensi Kemampuan Membaca dan Menulis Al-Qur'an

\begin{tabular}{|l|l|l|}
\hline Kriteria & Freq. & $\%$ Freq. \\
\hline Sangat baik & 0 & $0 \%$ \\
\hline Baik & 15 & $71 \%$ \\
\hline Cukup & 6 & $29 \%$ \\
\hline Kurang & 0 & $0 \%$ \\
\hline Sangat kurang & 0 & $0 \%$ \\
\hline Total & 21 & $100 \%$ \\
\hline
\end{tabular}


Berdasarkan tabel 2.9 diatas dapat diketahui bahwa, berdasarkan jumlah sampel penelitian sebanyak 21 madrasah, sebanyak 6 madrasah (29\%) termasuk dalam kategori cukup dan sisanya sebanyak 15 madrasah (71\%) termasuk dalam kategori baik, dan tidak ada madrasah yang termasuk dalam kategori sangat baik, kurang, dan sangat kurang.

Tabel 2.10

Distribusi Frekuensi Data Indikator Kemampuan Membaca dan Menulis Al-Qur'an

\begin{tabular}{|l|l|l|}
\hline \multirow{2}{*}{ Keterangan } & \multicolumn{2}{l|}{ BTQ } \\
\cline { 2 - 3 } & Freq. & \multicolumn{1}{l|}{$(\%)$} \\
\hline Average & 69.12 & \multicolumn{2}{|l|}{} \\
\hline Sangat baik & 119 & $24 \%$ \\
\hline Baik & 189 & $38 \%$ \\
\hline Cukup & 112 & $23 \%$ \\
\hline Kurang & 63 & $13 \%$ \\
\hline Sangat kurang & 12 & $2 \%$ \\
\hline Total & 495 & $100 \%$ \\
\hline
\end{tabular}

Berdasarkan tabel 2.10 diatas, dapat dijelaskan bahwa rata-rata kemampuan membaca dan menulis dari 495 siswa adalah sebesar 69.12, hal ini berarti kemampuan membaca dan menulis siswa termasuk dalam kategori baik karena berada pada rentang nilai $66-79$. Selanjutnya berdasarkan data distribusi frekuensi dapat dijelaskan bahwa, dari 495 siswa, sebanyak 119 orang (24\%) adalah siswa yang memiliki kemampuan membaca dan menulis siswa dalam kategori sangat baik, 189 orang (38\%) termasuk dalam kategori baik, 112 orang (23\%) termasuk dalam kategori cukup, 63 orang (13\%) termasuk dalam kategori kurang, dan sisanya sebanyak 12 orang (2\%) termasuk dalam kategori sangat kurang.

\section{Pendidikan Agama Islam (PAI)}

Dari sejumlah data yang dapat dianalisis, diperoleh deskripsi statistik untuk skor variabel Pendidikan Agama Islam dari masingmasing madrasah dan dari keseluruhan madrasah yang dapat dilihat pada tabel 2.11 dan grafik 2.4 berikut ini.

Tabel 2.11

Hasil Pengolahan Data Variabel Pendidikan Agama Islam

\begin{tabular}{|lc|}
\hline Madrasah & PAI \\
\hline MTsN 2 Makasar & 74.81 \\
\hline MTsN 1 Semarang & 80.45 \\
\hline MTsN 2 Semarang & 78.88 \\
\hline MTsN 8 JKT & 65.79 \\
\hline MTsN 11 JKT & 60.87 \\
\hline MTsN 10 JKT & 69.05 \\
\hline MTsN 12 JKT & 87.65 \\
\hline MTsN 27 JKT & 76.99 \\
\hline MTsN 35 JKT & 81.75 \\
\hline MTsN 1 BDG & 60.45 \\
\hline MTsN 2 BDG & 68.23 \\
\hline MTsN 1 SBY & 70.86 \\
\hline MTsN 2 SBY & 82.41 \\
\hline MTsN 3 SBY & 76.28 \\
\hline MTsN Rungkut SBY & 74.10 \\
\hline MTSN Kota Serang & 73.76 \\
\hline MTsN 1 Curug Serang & 43.28 \\
\hline MTsN 2 Jogja & 71.78 \\
\hline MTsN 1 Medan & 80.17 \\
\hline MTsN 2 Medan & 83.03 \\
\hline MTsN 3 Medan & 75.37 \\
\hline Average & 73.14 \\
\hline
\end{tabular}

Berdasarkan tabel 2.11 di atas dapat diketahui bahwa rata-rata kemampuan Pendidikan Agama Islam siswa adalah sebesar 73.14. Hal ini berarti kemampuan Pendidikan Agama Islam siswa termasuk dalam kategori baik karena berada pada rentang nilai 66 - 79 . Jika dilihat pada grafik 2.4 dapat diketahui bahwa terdapat beberapa madrasah yang masih memiliki nilai kemampuan Pendidikan Agama Islam dibawah rata-rata. 
Grafik 2.4

Nilai Pendidikan Agama Islam

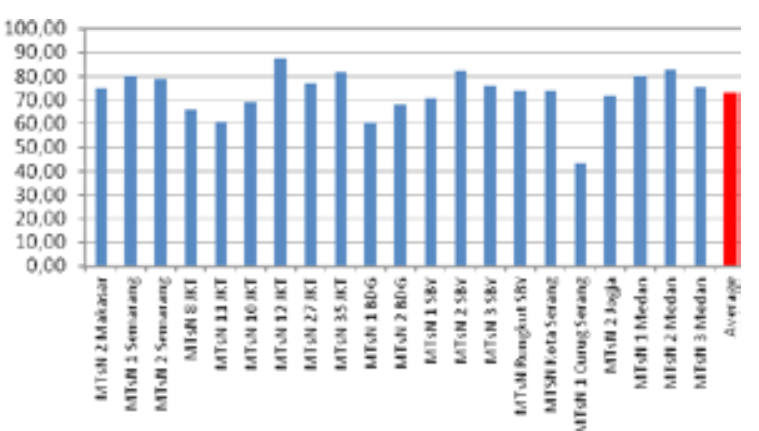

Selanjutnya data distribusi frekuensi Pendidikan Agama Islam siswa pada 21 madrasah yang termasuk dalam sampel penelitian akan ditunjukkan pada tabel 2.9 berikut ini.

Tabel 2.12

Distribusi Frekuensi Pendidikan Agama Islam Siswa

\begin{tabular}{|l|l|l|}
\hline Kriteria & Freq & $\%$ Freq \\
\hline Sangat baik & 6 & $29 \%$ \\
\hline Baik & 11 & $52 \%$ \\
\hline Cukup & 3 & $14 \%$ \\
\hline Kurang & 1 & $5 \%$ \\
\hline Sangat kurang & 0 & $0 \%$ \\
\hline Total & 21 & $100 \%$ \\
\hline
\end{tabular}

Berdasarkan tabel 2.12 diatas dapat diketahui bahwa, berdasarkan jumlah sampel penelitian sebanyak 21 madrasah, sebanyak 1 madrasah (5\%) termasuk dalam kategori kurang, 3 madrasah (14\%) termasuk dalam kategori cukup, 11 madrasah (52\%) termasuk dalam kategori baik, dan sisanya sebanyak 6 madrasah (29\%) termasuk dalam kategori sangat baik, dan tidak ada madrasah yang termasuk dalam kategori sangat kurang.

Dalam penelitian ini, kemampuan Pendidikan Agama Islam siswa diukur dengan menggunakan 5 indikator kemampuan yaitu mata pelajaran Quran Hadits, Fiqih, Akidah Akhlak, SKI, dan Bahasa Arab. Data distribusi frekuensi kemampuan Quran Hadits, Fiqih, Akidah Akhlak, SKI, dan Bahasa Arab secara lengkap dapat dilihat pada tabel 2.13 berikut ini.
Tabel 2.13

Distribusi Frekuensi Indikator Pendidikan Agama Islam Siswa

\begin{tabular}{|c|c|c|c|c|c|c|c|c|c|c|}
\hline \multirow{2}{*}{$\begin{array}{l}\text { Kete- } \\
\text { rangan }\end{array}$} & \multicolumn{2}{|c|}{ Qurdis } & \multicolumn{2}{|c|}{ Fiqih } & \multicolumn{2}{|c|}{ Aqidah } & \multicolumn{2}{|l|}{ SKI } & \multicolumn{2}{|c|}{ B. Arab } \\
\hline & Freq & $(\%)$ & Freq & $(\%)$ & Freq & $(\%)$ & Frea & $(\%)$ & Freq & $(\%)$ \\
\hline Average & \multicolumn{2}{|c|}{74.07} & \multicolumn{2}{|c|}{76.43} & \multicolumn{2}{|c|}{75.74} & \multicolumn{2}{|c|}{74.59} & \multicolumn{2}{|c|}{68.41} \\
\hline $\begin{array}{l}\text { Sangat } \\
\text { baik }\end{array}$ & 187 & $38 \%$ & 230 & $46 \%$ & 209 & $42 \%$ & 170 & $34 \%$ & 115 & $23 \%$ \\
\hline Baik & 211 & $43 \%$ & 183 & $37 \%$ & 209 & $42 \%$ & 244 & $49 \%$ & 188 & $38 \%$ \\
\hline Cukup & 59 & $12 \%$ & 54 & $11 \%$ & 44 & $9 \%$ & 56 & $11 \%$ & 104 & $21 \%$ \\
\hline Kurang & 30 & $6 \%$ & 25 & $5 \%$ & 32 & $6 \%$ & 23 & $5 \%$ & 48 & $10 \%$ \\
\hline $\begin{array}{l}\text { Sangat } \\
\text { kurang }\end{array}$ & 8 & $2 \%$ & 3 & $1 \%$ & 1 & $0.20 \%$ & 2 & $0.40 \%$ & 40 & $8 \%$ \\
\hline Total & 495 & $100 \%$ & 495 & $100 \%$ & 495 & $100 \%$ & 495 & $100 \%$ & 495 & $100 \%$ \\
\hline
\end{tabular}

Berdasarkan tabel 2.13 diatas dapat dijelaskan bahwa :

Pada indikator PAI Qurdis, rata-rata kemampuan PAI Qurdis siswa adalah sebesar 74.07, hal ini berarti kemampuan PAI Qurdis siswa termasuk dalam kategori baik karena berada pada rentang nilai $66-79$. Selanjutnya berdasarkan data distribusi frekuensi dapat dijelaskan bahwa, dari 495 siswa, sebanyak 187 orang (38\%) adalah siswa yang memiliki kemampuan PAI Qurdis yang sangat baik, 211 orang (43\%) termasuk dalam kategori baik, 59 orang (12\%) termasuk dalam kategori cukup, 30 orang (6\%) termasuk dalam kategori kurang, dan sisanya sebanyak 8 orang (2\%) termasuk dalam kategori sangat kurang.

Pada indikator PAI Fiqih, rata-rata kemampuan PAI Fiqih siswa adalah sebesar 76.43, hal ini berarti kemampuan PAI Fiqih siswa termasuk dalam kategori baik karena berada pada rentang nilai $66-79$. Selanjutnya berdasarkan data distribusi frekuensi dapat dijelaskan bahwa, dari 495 siswa, sebanyak 230 orang (46\%) adalah siswa yang memiliki kemampuan PAI Fiqih yang sangat baik, 183 orang (37\%) termasuk dalam kategori baik, 54 orang (11\%) termasuk dalam kategori cukup, 25 orang (5\%) termasuk dalam kategori kurang, dan sisanya sebanyak 3 orang (1\%) termasuk dalam kategori sangat kurang. 
Pada indikator PAI Aqidah, rata-rata kemampuan PAI Aqidah siswa adalah sebesar 75.74, hal ini berarti kemampuan PAI Aqidah siswa termasuk dalam kategori baik karena berada pada rentang nilai $66-79$. Selanjutnya berdasarkan data distribusi frekuensi dapat dijelaskan bahwa, dari 495 siswa, sebanyak 209 orang (42\%) adalah siswa yang memiliki kemampuan PAI Aqidah yang sangat baik, 209 orang (42\%) termasuk dalam kategori baik, 44 orang (9\%) termasuk dalam kategori cukup, 32 orang (6\%) termasuk dalam kategori kurang, dan sisanya sebanyak 1 orang (0.20\%) termasuk dalam kategori sangat kurang.

Pada indikator PAI SKI, rata-rata kemampuan PAI SKI siswa adalah sebesar 74.59, hal ini berarti kemampuan PAI SKI siswa termasuk dalam kategori baik karena berada pada rentang nilai $66-79$. Selanjutnya berdasarkan data distribusi frekuensi dapat dijelaskan bahwa, dari 495 siswa, sebanyak 170 orang (34\%) adalah siswa yang memiliki kemampuan PAI SKI yang sangat baik, 244 orang (49\%) termasuk dalam kategori baik, 56 orang (11\%) termasuk dalam kategori cukup, 23 orang (5\%) termasuk dalam kategori kurang, dan sisanya sebanyak 2 orang (0.40\%) termasuk dalam kategori sangat kurang.

Pada indikator PAI Bahasa Arab, ratarata kemampuan PAI Bahasa Arab adalah sebesar 68.41, hal ini berarti kemampuan PAI Bahasa Arab siswa termasuk dalam kategori baik karena berada pada rentang nilai 66 79. Selanjutnya berdasarkan data distribusi frekuensi dapat dijelaskan bahwa, dari 495 siswa, sebanyak 115 orang (23\%) adalah siswa yang memiliki kemampuan PAI Bahasa Arab yang sangat baik, 188 orang (38\%) termasuk dalam kategori baik, 104 orang (21\%) termasuk dalam kategori cukup, 48 orang (10\%) termasuk dalam kategori kurang, dan sisanya sebanyak 40 orang (8\%) termasuk dalam kategori sangat kurang.

\section{Perbandingan Nilai BTQ dan PAI}

Grafik 2.5

Hasil Pengolahan Data Perbandingan Nilai BTQ dan PAI

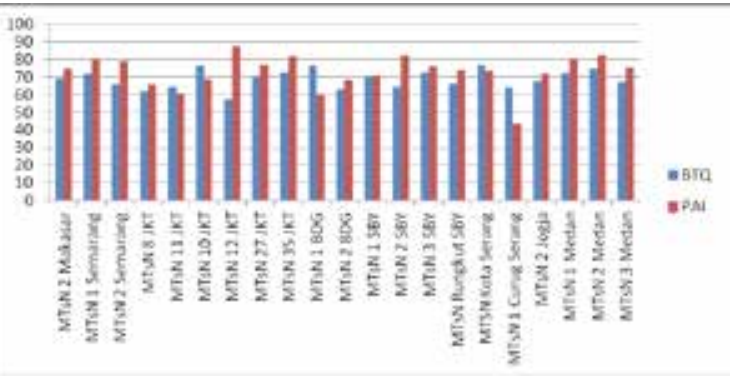

Grafik di atas menunjukkan perbandingan nilai rata-rata antara BTQ dan PAI siswa, dimana terlihat bahwa, sebagian besar madrasah mempunyai nilai rata-rata BTQ dan PAI yang tidak jauh berbeda.

Data dari grafik di atas menggambarkan perbandingan total nilai rata-rata BTQ dan PAI hanya berselisih 3\%. Hal ini menunjukkan bahwa ada kecenderungan nilai BTQ seiring dengan nilai PAI siswa. Jadi besar kemungkinan jika nilai BTQ meningkat nilai PAI semakin naik.

\section{Penguatan Pendidikan Agama Islam di Madrasah}

Berdasarkan hasil wawancara dengan pimpinan madrasah dan observasi ke madrasah didapatkan data-data terkait dengan penguatan pendidikan agama Islam di madrasah. Program-program penguatan keagamaan madrasah dilaksanakan dalam dua kegiatan yaitu pembelajaran dan pembiasaan. Kegiatan pembelajaran dilaksanakan melalui pembelajaran kurikuler dan pembelajaran ekstrakurikuler. Sedangkan pembiasaan dilakukan dengan menerapkan program school culture (budaya sekolah/madrasah) yang terkait dengan perilaku akhlakul karimah, pembiasaan ibadah, pembiasaan membaca alQur'an (tartil) dan praktek ibadah. 
Pembelajaran kurikuler, berupa kegiatan belajar mengajar PAI yang terdiri dari mata pelajaran Fiqih, SKI, Akidah Akhlak, Al-Qur'an Hadis dan juga Bahasa Arab. Kegiatan kurikuler PAI tersebut dilakukan di seluruh madrasah sasaran. Sedangkan kegiatan ekstrakurikuler PAI dilakukan dalam berbagai bentuk, yaitu: pembelajaran praktek ibadah, Baca Tulis Al-Qur'an/BTA dan Qira'ah serta praktek bahasa Arab. Pembelajaran praktek ibadah dilaksanakan dalam beberapa kegiatan seperti salat, wudlu, mengurus jenazah, praktek ibadah haji dan lain-lain.

Untuk menunjang kelancaran kegiatan praktek ibadah, madrasah melengkapi dengan sarana LCD dengan memutarkan film-film bertema keagamaan dan film tentang tata cara beribadah. Sedangkan kegiatan Baca Tulis Al-Qur'an/BTA dan Qira'ah, diselenggarakan dalam upaya membantu siswa lancar dalam membaca dan menulis Al-Qur'an. Sedangkan Qira'ah adalah kegiatan belajar melantunkan ayat-ayat suci yang lebih indah. Dari kegiatan ini, ada sebagian siswa yang telah memiliki kemampuan melantunkan ayat-ayat suci al-Qur'an (qira'ah) dan pernah mengikuti berbagai lomba tilawatil Qur'an tingkat daerah. Kegiatan BTA dan Qira'ah ini, pelaksanaannya dikoordinasikan oleh tenaga khusus pembina BTA dan Qira'ah.

Setiap awal tahun ajaran baru, misalnya di MTsN Serang, melakukan pemetaan kemampuan siswa baru dalam membaca dan menulis Al Qur'an. Setelah dipetakan, bagi siswa yang belum dapat membaca dan menulis $\mathrm{Al}$ Qur'an akan diberi treatment khusus berupa pelajaran tambahan membaca dan menulis Al Qur'an. Kegiatan penguatan membaca dan menulis Al Qur'an bagi siswa yang belum mampu ini diberikan 4 kali dalan satu minggu yaitu setiap hari Senin sampai hari Selasa pada pukul 14.00 - 15.00 WIB. Dengan kegiatan penguatan ini diharapkan siswa sudah bisa membaca dan menulis Al Qur'an saat mereka naik ke kelas VIII. Hal yang sama dilakukan oleh MTsN 1 Surabaya. MTsN 1 ini dalam upaya penyeragaman kemampuan minimal dalam hal baca Al-Qur'an, kepada siswa - siswi kelas 7 diberikan program Bimbingan Baca Al-Qur'an (BBQ), serta pengembangan life skill dalam hal berbahasa Arab bagi siswa kelas 8. Penguatan ini ditambah lagi dengan materi muatan lokal Hifdzul Qur'an per minggunya sebanyak 1 jam untuk kelas VII dan VIII.

Kegiatan ekstrakurikuler lainnya berupa praktek ibadahyang diselenggarakan seminggu sekali. Kegiatan ini dilakukan untuk melatih siswa dalam berbahasa Arab. Oleh karena itu, pembelajaran bahasa Arab ini dilaksanakan dalam bentuk percakapan, namun dengan tema-tema percakapan tertentu yang sudah ditetapkan. Kegiatan ini dipimpin oleh guru bahasa Arab dan dilaksanakan di laboratorium bahasa dengan menggunakan sarana yang telah ada.

Penguatan PAI dalam bentuk pengembangan diri juga dilakukan oleh beberapa madrasah. Pengembangan diri sebagai pengembangan bakat bersifat pilihan. Kegiatan pengembangandiri sebagaiberikut:(1)PHBI dan PHBN meliputi peringatan Isra' Miraj, Tahun Baru Hijriyah, Maulid Nabi dan Idul Adha serta Peringatan HUT RI. Kegiatan ini melibatkan seluruh warga madrasah baik peserta didik dan guru. Kegiatan ini dapat berbentuk lomba antar kelas baik lomba akademik maupun non akademik yang bertujuan untuk mengetahui potensi diri peserta didik atau dapat berbentuk kegiatan tausiyah atau ceramah agama dengan mengundang penceramah dari luar madrasah. (2) Pondok Ramadhan. Kegiatan Pondok Romadhan dilaksanakan oleh seluruh peserta didik untuk melatih kemandirian serta meningkatkan keimanan dan ketakwaan peserta didik. Dilaksanakan pada bulan Romadhan setiap tahunnya, dimana seluruh siswa bermalam di madrasah sesuai dengan jadwal yang telah disusun oleh panitia. Pengisi materi selain berasal dan lingkungan madrasah juga melibatkan pihak luar. (3) Wisata Rohani, Tadabur Alam dan Studi Wisata. Merupakan program madrasah yang disepakati bersama 
walimurid. Kegiatan mi merupakan bentuk pembelajaran di luar kelas. Wisata Rohani untuk peserta didik kelas 7 yang bentujuan memperkenalkan kepada peserta didik tentang sejarah Islam yang ada khususnya di wilayah Jawa Timur serta penerapan mata pelajaran Fikih. Untuk Tadabur Alam dilaksanakan oleh peserta didik kelas 8 yang merupakan aplikasi dan mata pelajaran IPA, IPS , Bahasa Inggris, Bahasa Indonesia,SeniBudaya. SedangkanStudi Wisata dilaksanakan oleh peserta didik kelas 9. (4) Khotmil Qur'an. Kegiatan mi dilaksanakan pada setiap akhir tahun pelajaran, merupakan puncak dan kegiatan Bimbingan Baca Qur'an (BBQ) yang diikuti oleh peserta didik kelas 7 . Khotmil Qur'an menampilkan peserta kegiatan BBQ yang terpilih

hafidz/hafidzoh) untuk malantunkan hafalan Juz Amma di depan seluruh undangan yang terdiri dan walimurid kelas 7 , guru serta tamu undangan lainnya.

Pembiasaan berperilaku akhlakul karimah antara lain siswa dibiasakan untuk senantiasa mengucapkan salam kepada siapapun ketika bertemu, menjaga kebersihan kelas dan lingkungan madrasah, berdoa sebelum dan sesudah belajar, menjenguk temannya yang sedangsakit,salingmengasihidanmenghormati sesama teman, guru dan karyawan lainnya $\mathrm{dsb}$. Sedangkan pembiasaan ibadah antara lain siswa dibiasakan untuk melaksanakan sholat duha yang dilakukan pada jam istirahat dan salat duhur berjamaah. Terkait dengan shalat jamaah ini, karena mushala tidak mampu menampung seluruh siswa, maka kegiatan shalat jamaah dilakukan secara bergiliran sesuai jadwal, dan penjadwalan ini dilakukan oleh GPAI.

Pembiasaan melakukan tadarus atau tartil al-Qur'an juga menjadi salah satu program school culture. Kegiatan ini dilakukan sepuluh menit menjelang kegiatan pembelajaran dimulai. Ini dilakukan untuk melatih siswa agar mencintai al-Qur'an dan senang membaca al-Qur'an serta mampu mengamalkan ajaranajaran al-Qur'an. Disamping itu, melalui kegiatan ini sekaligus melatih siswa untuk memperbaiki tajwid dan makhraj dalam membaca al-Qur'an. Di beberapa madrasah dilakukan kegiatan yang diarahkan untuk pembiasaan, yaitu: (1) membaca Al-Qur'an setiap pagi sepuluh menit sebelum jam pertama dimulai dipandu oleh guru yang mengajar pada jam pertama, (2) membaca do'a awal dan akhir pelajaran secara central dipandu oleh salah satu siwa secara bergilir, (3) sholat dhuha bersama yang dilaksanakan secara bergilir sesuai dengan jadwal yang telah disusun, dan dilaksanakan sebelum jam ke 0, (4) sholat dhuhur berjama'ah dilaksanakan setiap hari efektif dengan dipandu oleh guru pendamping, dan(5) sholat Jum'at dilaksanakan pada setiap hari Jum'at efektif

\section{PENUTUP}

\section{Kesimpulan}

Dari hasil penelitian "Kemampuan bacatulis Al-Qur'an dan Penguatan Agama siswa Madrasah" ini dapat disimpulkan sebagai berikut:

a. Kemampuan membaca dan menulis AlQur'an siswa MTsN di kota-kota besar di Indonesia dalam kategori baik. Namun kemampuan menulis Al-Qur'an masih lebih rendah daripada kemampuan membaca AlQur'an Siswa, yaitu sebagian besar siswa rata-rata kemampuan menulisnya masih dalam kategori cukup.

b. Implementasi program penguatan agama di madrasah telah dilaksanakan sebagian besar MTsN melalui kegiatankegiatan pengembangan dan penguatan agama secara bervariatif, baik melalui kegiatan intrakurikuler, muatan lokal dan dalam proses pembelajaran PAI. Hal ini menunjukkan bahwa penguatan PAI sebagaimana tertuang dalam Peraturan Menteri Agama Nomor 2 tahun 2008 telah berjalan, namun sarana dan sumber belajar PAI belum terpenuhi di seluruh madrasah 
dan sarana yang tersedia pemanfaatannya belum optimal.

\section{Rekomendasi}

Dengan memperhatikan hasil penelitian ini maka rekomendasi yang diusulkan adalah sebagai berikut:

a. Direktorat Jenderal Pendidikan Islam melalui Direktorat Pendidikan Madrasah perlu mengevaluasi pelaksanaan program penguatan agama di madrasah, penambahan 10 jam pelajaran PAI dan bahasa Arab di madrasah masih belum optimal pelaksanaannya.

b. Direktorat Pendidikan Madrasah perlu menyusun pedoman pelaksanaan program penguatan agama yang sejalan dengan program penguatan kemampuan membaca dan menulis Al-Qur'an di Madrasah, baik dalam program pembelajaran PAI, program intra kurikuler maupun dalam muatan lokal.

c. Madrasah perlu mengoptimalkan perencanaan program penguatan agama dan penguatan membaca dan menulis Al-Qur'an, melalui pembelajaran PAI, program intra kurikuler, muatan lokal dan program lainnya, bekerjasama dengan lembaga pendidikan keagamaan di masyarakat. Madrasah perlu meningkatkan kompetensi guru PAI dalam penguatan materi agama melalui peningkatan kemampuan membaca dan menulis AlQur'an, khususnya penguatan kemampuan menulis Al-Qur'an.

\section{SUMBER BACAAN}

Azra, Azyumardi (2002): Pendidikan Islam: Tradisi dan Modernisasi Menuju Milenium Baru. Jakarta, Logos,

Daryanto (2010): Evaluasi Pendidikan. Jakarta, Penerbit Rineke Cipta,

Singarimbun. Masri (1995): Metode Penelitian Survai. Jakarta, LP3ES.

Miles, Mathew B., dan Huberman, Michael A. Analisis Data Kualitatif: Buku Sumber tentang Metode-metode Baru. Terjemahan Tjetjep R. Rohidi, Jakarta: UI Press.

Arikunto, Suharsimi (2006): Prosedur Penelitian Suatu Pendekatan Praktek. Jakarta, Rineka Cipta

Puslitbang Pendidikan Agama dan Keagamaan. (2010): Penelitian tentang Efektivitas Kebijakan Pemerintah Daerah Tentang Bacatulis Al-Qur'an Dalam Perspektif Peningkatan Mutu Pendidikan Agama, Jakarta

Peraturan Pemerintah Nomor 19 Tahun 2005 tentang Standar Nasional Pendidikan (Lembaran Negara Republik Indonesia Tahun 2005 No. 41, Tambahan Lembaran Negara Nomor 4496).

Peraturan Menteri Pendidikan Nasional Nomor 22 tahun 2006 tentang Standar Isi dan Nomor 23 Tahun 2006 tentang Standar Kompetensi Lulusan untuk Pendidikan Dasar dan Menengah.

Peraturan Menteri Agama Nomor 2 tahun 2008 tentang Standar Kompetensi Lulusan dan Standar Isi Pendidikan Agama Islam dan Bahasa Arab di Madrasah. 